\title{
THE LINGUISTICS OF IMAGINARY NARRATIVE SPACES IN DAPHNE DU MAURIER'S REBECCA
}

\author{
John Newman \\ john.newman@ualberta.ca \\ University of Alberta, Canada \\ Monash University, Australia
}

Received December 4, 2018; Revised December 24, 2018; Accepted December 26, 2018

\begin{abstract}
Daphne du Maurier's 1938 novel Rebecca provides rich opportunities for the study of imaginary narrative spaces and the language associated with such spaces. The present study explores the linguistics of the imaginary narrative spaces in Rebecca, drawing upon three lines of linguistic research consistent with a Cognitive Linguistic approach: (i) an interest in understanding and appreciating ordinary readers' actual responses (rather than merely relying upon "expert" readers' responses), (ii) the construction of worlds or "spaces", and (iii) the application of ideas from Cognitive Grammar. The study reveals a surprisingly intricate interplay of linguistic devices used in the construction of imaginary narrative spaces and the maintenance of such spaces in extended discourse.
\end{abstract}

Keywords: imaginary narrative space, du Maurier, cognitive linguistics, cognitive grammar, stylistics, repetition.

\section{Ньюман Джон. Лінгвістика уявних наративних просторів у романі «Ребекка» Дафни дю Мор'є.}

Роман «Ребекка» Дафни дю Мор’є 1938 року надав великі можливості для вивчення уявних наративних просторів й мовлення, яке прийнято асоціювати 3 ними. У цьому дослідженні увагу приділено лінгв істиці уявних наративних просторів у романі «Ребекка». Автор розглядає три лінії лінгвістичних досліджень у річищі когнітивно- лінгвістичного підходу, а саме: а) зацікавлен ість у розумінні та оцінці реальних в ідпов ідей читачів (замість того, щоб просто покладатися на «експертні» відповіді читачів); б) побудова світів або «просторів»; в) застосування ідей когнітивної граматики. Дослідження виявило доволі заплутану й складну взаємодію мовних засобів, які використов ує автор роману для побудови уявних наративних просторів й утримання таких просторів у подальшому дискурсі.

Ключові слова: уявний наративний простір, дю Мор'є, когнітивна лінгвістика, когнітивна граматика, стилістика, повторення.

\section{Introduction}

Among the more recent developments in the field of linguistics and the many attempts to strike new paths in linguistic theorizing and new methods of linguistic analys is, Cognitive Linguistics stands out as one of the most successful. Cognitive Linguistics is characterized in broadest terms as an approach to the study of language that is concerned with general principles that provide some explanation for all aspects of language, consistent with what is known about human cognition generally (Dancygier, 2017a; Evans \& Green, 2006). While the study of literature has hardly been a primary focus within the Cognitive Linguistics movement, it is nevertheless an area of growing interest (cf. Dancygier, 2017b; Harrison \& Stockwell, 2014; Stockwell, 2002). A very obvious area in which Cognitive Linguistics has contributed to the study of literature is metaphor, understood as a

(C) Newman, John, 2018. This is an Open Access article distributed under the terms and conditions of the Creative Commons Attribution 4.0 International Licence (http://creativecommons.org/ licenses/by/4.0).

East European Journal of Psycholinguistics, 5(2), 42-61. https://doi.org/10.5281/zenodo.2583506 
conceptual mapping from a source domain to a target domain (see especially Lakoff \& Turner, 1989; Turner, 1996). There are, however, numerous other ways in which a Cognitive Linguistic orientation may inform the study of literature and the present study is intended as an example of how the study of a literary text can profitably draw upon various ideas current in Cognitive Linguistics.

The primary goal of this study is to explore, from a Cognitive Linguistic perspective, the range of linguistic devices associated with imaginary narrative spaces in one particular novel Rebecca, written by the English writer Daphne du Maurier, and first published in 1938. As explained below, the novel is particularly relevant to the study of imaginary spaces in literature and is a very suitable object of study for linguists with an interest in the role of language in the construction and maintenance of imaginary spaces. A secondary goal of the study, following from the findings relating to the first goal, is to add to our understanding of the aesthetics of repetition of form, or alternately, variation in form in literary writing.

I introduce the Cognitive Linguistic orientation of the paper, the novel that is the source of data, and the notion of imaginary narrative spaces in Section 2. Sections 3 presents the analysis and discussion of results and Section 4 is the conclusion.

\section{Methods}

\subsection{Cognitive Linguistic Perspectives}

Three Cognitive Linguistic strands of research relevant to the present study are: (i) readers' actual responses and cognitive processes, (ii) the construction of worlds or "spaces" within the novel, and (iii) the application of ideas from Cognitive Grammar. Each of these aspects of the present approach is briefly elaborated below.

The consideration of readers' actual responses to a literary text, as opposed to responses of purely "expert" readers (academics and professional literary critics), is consistent with an interest in Cognitive Linguistics in the cognitive experience associated with the use of language. The study of the mental processes associated with reading literature, the study of the actual aesthetic experiences associated with reading literature, etc. are all of interest from a Cognitive Linguistic perspective, however difficult it might be to establish appropriate experimental methods. The present study is not an experimental study, but nevertheless it does turn to the responses of ordinary readers (as evidenced in online reviews) to confirm certain qualities of the novel (in Sections 2.3 and 2.3), rather than relying exclusively upon my own reading of the text or that of expert readers. In this way, the analysis offered here incorporates aspects of the experienced reality of readers of the text, rather than being a purely textual analysis without reference to cognitive realities.

The construction of mental spaces has been a continuing area of interest in Cognitive Linguistics, following in large part from the work of Fauconnier (1985). This work has also informed subsequent research on metaphor and 'conceptual mapping', i.e. the mapping from one conceptual domain to another conceptual domain and the manner in which new understandings emerge from the blending of elements in a unified domain (Turner, 2015). In the case of the present study, the 
interest lies in imaginary narrative spaces, i.e., passages of text within the narrative of the story that take the reader mentally to imagined scenes and events.

I draw upon Cognitive Grammar, especially as presented by Langacker (1991), in order to better understand the conceptual dynamics associated with imaginary narrative spaces in the novel. The Cognitive Grammar framework provides an intuitively satisfying approach to understanding the functions of linguistic forms in language and communication. It is a key theoretical framework and source of inspiration for many researchers in the field of Cognitive Linguistics (see Harrison et al., 2014, for a selection of studies of literature grounded in Cognitive Grammar specifically). Many of the psychologically grounded concepts of Cognitive Grammar have natural applications to literature (figure vs. ground, summary vs. sequential scanning, a stage model of conceptualizing our observation of external events, etc.). In the present study, the Cognitive Grammar notion of a cognitively grounded epistemic model is incorporated into the analysis of imaginary narrative spaces in Section 3.

\subsection{Rebecca, the Novel}

The novel under discussion in the present study is Rebecca, written by the English writer Daphne du Maurier and first published in $1938^{1}$. The novel proved popular at the time it was published and has remained popular ever since, available in translation in many languages. It was also made into a highly successful film directed by Alfred Hitchcock, in 1940, adding to the reputation of the novel and its author ${ }^{2}$.

My concern here is not with the development of the plot or characters, and it is not necessary to explain these aspects of the novel in any detail. Nevertheless, a short summary of the novel at this point may be useful. Very briefly, the novel takes the form of a recollection of (usually distressing) events surrounding the marriage of the narrator, who remains unnamed, to a widower Maxim de Winter. The narrator meets Maxim as a young, naïve woman and soon finds herself having to contend with the strong memory of Maxim's first wife, Rebecca, on the part of Maxim and his friends, family, and servants, especially the housekeeper Mrs. Danvers. In time, it is revealed to the narrator by Maxim that he had killed Rebecca and had made it look as though Rebecca had died in a boating accident. Most of the events of the novel take place in and around Maxim's mansion in Cornwall, Manderley, which is burnt to the ground as the final climax of the novel.

The reception of the novel among literary critics has not matched the popular success that the novel has enjoyed, though there has been some change over the years in how the novel is viewed in academic and literary circles. Earlier critics tended to dismiss the novel as a romance, a category of writing that is supposedly common, mundane, and without special interest for serious or sophisticated readers (cf. Beauman, 2003, p. 431; Kelly, 1987, pp. 62-63). In an overview of English

\footnotetext{
${ }^{1}$ Citations of the novel in this study are taken from the Virago Press edition of Rebecca published in 2012.

${ }^{2}$ Rebecca is one of three published works by du Maurier that were made into films directed by Hitchcock, the other two being the novel Jamaica Inn and the short story The Birds.
} 
novelists, Winifrith (1979) does consider the novel to have risen above simply a "period piece", but still draws attention, negatively, to the "romantic settings and Byronic heroes without any corresponding exploitation of human motivation or ordinary life" present in this and other novels by the author (pp. 355-356).

This earlier view has since been fiercely contested in some quarters. Kelly (1987, p. 54) for example, considers the novel to be "a profound and fascinating study of an obsessive personality, of sexual dominance, of human identity, and of the liberation of the hidden self". And the same author considers the neglect of the novel in some circles to be due to "literary saints", snobbery, and sexism (p. 63). Beauman refers to the novel as "strange, angry and prescient" in the reflection on its critical history in (1):

(1) Rebecca, from the time of first publication, has been woefully and wilfully underestimated. It has been dismissed as a gothic romance, as 'women's fiction'- with such prejudicial terms, of course, giving clues as to why the novel has been so unthinkingly mis interpreted. Re-examination of this strange, angry and prescient novel is long overdue. (Beauman, 2003, p. 429)

An earlier view of the novel as simple romantic fiction has been replaced by a view of the novel as having considerable more substance and relevance, especially with respect to the psychological complexity of characters, including the female characters and their relationships with one another (cf. Armitt, 2000, p. 104; Hadiyanto, 2010; Horner \& Zlosnik, 1998; Margawati, 2010). Any idea that du Maurier is a writer of typical romantic fiction has long since disappeared - Birch (2003), for example, refers to du Maurier's "refusal of romantic comforts" in her writing. Interestingly, the change in the status of the novel among literary and academic writers is mirrored to some extent in the change of opinion that particular readers have expressed. The comments in (2) are taken from the online reviews of the novel by one reader to be found at "goodreads.com". The writer reports her change in the evaluation of the novel as a love story (when she was a very young girl) to a "gorgeously intense psychological thriller" now.

(2) ...I read this novel as a very young girl, and remembered it as a love story. ...However, as life tosses and turns one around, I felt compelled to reread it on a too hot, oppressive summer day. And I was captivated, quite despite myself. What a gorgeously intense psychological thriller this is! (From "Lisa", goodreads.com reviews)

\subsection{Imaginary narrative spaces}

In the present study, the text passages of interest are those where the narrator takes herself and the reader into realms of imagination far removed from the immediate reality surrounding the narrator at that point in the story. These passages vary from relatively short (a few sentences) to relatively long (a whole chapter).

\footnotetext{
${ }^{3}$ See https://www.goodreads.com/book/show/17899948-rebecca
} 
There have been various analytical frameworks and accompanying labels proposed to describe the form and content of passages such as these. In particular, appeals to 'worlds' and 'spaces' have become common. Werth's (1999) notions of 'text world' and 'sub-worlds' as applied to texts has been influential and informs Stockwell's (2002) discussion of worlds in the analysis of literary texts, which include fantasy worlds as a sub-class of a more general category of discourse worlds (pp. 91-96). Fantasy worlds, by his definition, refers to the "the worlds of characters' dreams, visions, imaginations or fictions that they compose themselves" and this characterization does seem appropriate for the content we encounter in the relevant passages in the novel (see also the discussion of text-worlds by Gavins, 2007). A different tradition relying upon the notion of 'spaces' has also evolved, originating in Fauconnier's (1985) study of 'mental spaces'. Dancygier (2012, p. 36) relies upon the idea of 'narrative spaces' to refer to these sub-parts of a text that take the reader to different kinds of realms. While 'worlds' or 'spaces' might seem equally apt as ways of capturing the passages being studied below, I adopt Dancygier's terminology of 'narrative spaces' in order to indicate a closer connection of the present study to Dancygier's overall approach than to, say, Werth's approach. Two aspects of Dancygier's approach apply, in particular, to the present study: "Narrative spaces are defined in parallel to and in correlation with lower-level linguistic phenomena participating in meaning construction, and, while they may apply to 'worldlike' constructs, they do not apply to texts in their entirety" (Dancygier, 2012, p. 36). This explicit interest in lower-level linguistic phenomena associated with narrative spaces and the interest in narrative spaces as smaller parts of an entire text can be seen also in the approach I adopt here. It is fitting therefore to situate the present study in a tradition of studying narrative spaces, here imaginary narrative spaces, rather than text worlds.

The decision to focus attention on imaginary narrative spaces in the novel is grounded in a perception that these spaces, taken together, are highly effective devices in constructing the character of the narrator, the key player in the drama of the novel. But, importantly, these spaces are also a highly salient aspect of the whole novel and are pointedly commented upon both within the novel and by readers of the novel. The extracts in (3) illustrate some of the explicit references to dreams and dreaming within the novel. In (3a), Mrs. Van Hopper, the American woman for whom the narrator in the early part of the novel works in the capacity of a companion, addresses the narrator and refers to the 'dreaming' that she supposes the narrator has been absorbed in. In (3b), the narrator identifies herself as a dreamer as part of the retelling of the extended dream that makes up Chapter 1. In (3c) the narrator describes herself on one occasion as being in "a sort of dream" in the company of her husband. Even though words like dream, dreaming etc. are explicitly used in these and other passages in the text, one might well question whether dreaming and its related forms are in fact accurate descriptions of what has transpired. ( $3 b)$ is part of the narrator's retelling of a dream that came to the narrator the preceding night. Here there is no question that a dream, as usually understood, is being described and that the narrator was the dreamer. In (3a), however, Mrs. Van 
Hopper assumes the narrator has been 'dreaming' when in fact the narrator has been experiencing something more like a neurotic episode, crouched on the floor by herself in the bathroom (see Section 6 for more discussion of this scene).

(3) a. "You can't afford to dream this morning, you know, there's too much to be done." (p. 53)

b. Then, like all dreamers, I was possessed of a sudden with supernatural powers and passed like a spirit through the barrier before me. (p. 1)

c. I had sat there on the floor beside Maxim in a sort of dream, his hand in mine, my face against his shoulder. (p. 319)

Apart from these explicit references to dreaming within the novel, readers of the novel have drawn attention to such passages as part of their general commentaries on the "goodreads.com" website. While I have not attempted to sample these commentaries in any systematic way, the examples of commentaries in (4) are sufficient to illustrate a range of ways in which ordinary readers react to the imaginary narrative spaces in the novel, all taken from "goodreads.com". The "Navessa" reader in (4a) refers to the narrator as a dreamer and how any number of events can "send her mind spinning, as she plays out the infinite consequences of these things". Clearly, "Navessa" had a relatively negative view of these qualities of the novel, and found the novel more difficult to read because of them. The readers making the comments in (4b-c) are also struck by passages of the text, referred to as "daydreams", "ruminations", and "naïve neurotic thoughts" (cf. also Naszkowska's (2012, p. 133) reference to Manderley, the setting of most of the novel, as a 'dreamscape').

(4) a. What made it that much more difficult to read was the MC [Main Character]. [The narrator] is a dreamer; she lives largely inside of her head, and the smallest thing, from her companion choosing to host a cocktail party, to the rising of the sun, can send her mind spinning as she plays out the infinite consequences of these things. This tendency becomes obsessive when Maxim enters the picture. ("Navessa", rating of $2 / 5$ where 5 is the most positive score, goodreads.com reviews)

b. I have to say that the second Mrs. de Winter's paralyzing lack of selfconfidence and her gaucherie, even though integral to the plot, was really irksome to me. And every time she'd start off into another daydream, which she did All. The. Time., imagining conversations and events out of whole cloth, I would mentally roll my eyes at her. But once I realized that this is not to be read as a romance novel (really, the relationship here is pretty unhealthy on both sides), I was free to appreciate the characters' shortcomings (instead of being frustrated by them) and to see how those shortcomings and their past experiences combine to bring them together, 
but pull them apart at the same time. It's a fascinating psychological study. ("Tadiana", rating of 5/5, goodreads.com reviews)

c. Oh my... how I fell in love with this classic novel, I adored the main protagonist and felt she was fully developed as a character. Her constant ruminations and daydreams really set the tone it's a real trip getting to be inside her head with all her naive neurotic thoughts, which often get carried away and make for a compelling read. ("Vanessa", rating of 5/5, goodreads.com reviews)

This propensity of the narrator towards flights into realms of imagination reflects, too, an aspect of du Maurier's own childhood experiences. Forster (1993, p. 8) refers to the "marvellous imaginative games" that du Maurier's father played with his daughters and how the du Maurier daughters "were encouraged, even expected, to use their imaginations" (p. 10). In fact, du Maurier has been characterized as an "addict of fantasy" in Birch's (2007) appreciative re-appraisal of the author.

\section{Results and Discussion}

\subsection{Establishing imaginary narrative spaces}

We will take a close look at six examples of how imaginary narrative spaces are created in the novel, illustrating the types of spaces imagined and the variety of linguistic means used ${ }^{4}(5)$ is an example of an imagined reality using the present perfect. The use of $I$ think makes it explicit that this is an imaginary space. The parenthetical use of I think in this example helps to background the role of the narrator in thinking these thoughts, giving more immediacy to the experience of the narrated events (someone telling her, someone seeing us together, etc.). There is, furthermore, an effect of hurriedness, almost of uncontrollability, in the quick succession of verb phrases lacking any unnecessary elaboration. It is not until we reach and I waited for her attack that the imagining of events comes to an end and the narrator returns to present reality.

(5) Someone has told her, I thought, someone has seen us together, the tennis professional has complained, the manager has sent a note, and I waited for her attack. (p. 46)

The excerpt in (6) is similar to (5) in that it involves an explicit I thought. Here, the I thought introduces the sequence of imagined scenes, positioned at the beginning of the sequence. (6) concerns an imagined future, rather than an imagined past, with simple future modal auxiliaries shall/will throughout. As in (5), there is an effect of hurriedness in the juxtapositioning of the clauses.

\footnotetext{
${ }^{4}$ I use bold style to draw attention to particular linguistic features of interest.
} 
(6) I thought, I shall never drive with him again. To-morrow he will go away. And Mrs. Van Hopper will be up again. She and I will walk along the terrace as we did before. The porter will bring down his trunks, I shall catch a glimpse of them in the luggage lift, with new-plastered labels. (p. 41)

The excerpt in (7) takes the reader to an alternative imagined space through the I saw myself $V$-ing construction. The time in which the imagined events in (6) take place is neither past nor distant future, but rather an alternative to now or the immediate future. Here there is more intervening text between the verb forms that describe the actions of the narrator, compared with (5) and (6). Altogether, the effect is of a more leisurely imagined space.

(7) I saw myself strolling into Mrs. Van Hopper's bedroom rather late for my bezique, and when questioned by her yawning carelessly, saying, "I forgot the time. I've been lunching with Maxim.” (pp. 45-46)

In (8), the imaginary space is introduced through an if..., then ... construction in which the past tense form appears in the if-clause, indicating here an imagined nearfuture space, the "subjunctive" function of the simple past tense. This construction, with a past tense form in the if-clause requires a modal auxiliary in the then-clause. And in (8), we find should, would, and could all being used as part of an extended if..., then ... construction.

(8) If I rang him up again at the office now I should find that he had gone. The clerk would say "Mr. Crawley has just gone out,' Mrs. de Winter," and I could see Frank, hatless, climbing into his small, shabby Morris, driving off in search of Maxim. (pp. 267-277)

As with (8), the excerpt in (9) makes use of modal auxiliaries, here could and should, to establish and maintain an imaginary space in a vague future time. However, in this case, there is no if..., then ... construction to formally indicate the transition from reality to the imagined space. The narrator moves directly into imagined space through the 'stand-alone' use of these hypothetical modals, unsupported by any formal lexical or syntactic device explicitly signalling the transition. The cohesion of the passage is all the stronger because of the repeated $I$ could/should both overtly and covertly since it is I could/should that is understood as the missing elements of the conjoined clauses, as in I could go to the morningroom and sit down at her desk and touch he pen and look at her writing on the pigeon-holes.

(9) Now that I knew her to have been evil and vicious and rotten I did not hate her any more. She could not hurt me. I could go to the morning-room and sit down at her desk and touch her pen and look at her writing on the pigeonholes, and I should not mind. I could go to her room in the west wing, stand 
by the window even as I had done this morning, and I should not be afraid. (pp. 319-320)

Finally, in (10), we see quite a different combination of linguistic resources to describe the imaginary space. The passage introduces the imagined space by setting the stage with $A$ hundred images came to me..., preparing the reader for a string of images. These images are presented as a sequence of elaborated noun-phrases, one after the other, without any of the conventional supporting syntactic apparatus of fully-formed clause structure.

(10) A hundred images came to me when I closed my eyes, things seen, things known, and things forgotten. They were jumbled together in a senseless pattern. The quill of Mrs. Van Hopper's hat, the hard straight-backed chairs in Frank's dining-room, the wide window in the west wing at Manderley, the salmon-coloured frock of the smiling lady at the fancy dress ball, a peasantgirl in a road near Monte Carlo. (p. 424)

As pointed out above, the usage of the should/would modals in (9) should be differentiated from their very familiar use in the consequent clause, also called 'apodosis', of a hypothetical if..., then ... construction, as in (8): If I rang him up again at the office now I should find that he had gone. In this construction, a modal in the then-clause is required. Huddleston \& Pullum (2002) are explicit: "The apodosis of a remote conditional must contain a modal auxiliary" (p. 199). The hypothetical modals should/would in (9), however, appear outside of the if ..., then ... construction in what one might call a 'bare' hypothetical use of modals. The instances of the modals in (9) are different, too, from cases like I would advise against signing the document, where the function of the modal is to attenuate, or soften, the illocutionary force, not to conjure up a hypothetical world. To say $I$ would advise against signing the document is, in fact, to advise (not to hypothesize), but in a polite way.

Although both should and would can be used as bare hypothetical modals in present-day English, the use of should (primarily with $1^{\text {st }}$ person singular subject) is relatively rare. In Biber et al. (1999, p. 496), there is a brief, passing mention of would having a hypothetical meaning outside of the conditional if..., then... construction (I would give it back is an example they use), but no mention of a similar use of should. Palmer (1974, pp. 139-151) is an extended discussion of the role of modals including would and should, in conditional sentences (e.g., If you were to go, I should be angry). Palmer (p. 138) notes that the past tense forms of the modals would, might, and couldn't can be used with "tentative" meaning (outside of the if..., then ... construction), as in He would be there, but no mention is made of should being used this way. To give some sense of the relative frequency of usage of should and would historically, one can make use of Google's N-gram Viewer".

\footnotetext{
${ }^{5}$ Google's Ngram Viewer is accessible at https://books. google.com/ngrams.
} 
Figure 1 is a graph showing the comparative use of the specific phrases I should think and I would think (just to take one example, of a frequent should/would combination) in the corpus of English Fiction 1800-2000. It can be seen how the use of should has been steadily declining in the twentieth century, with I should think undergoing a distinct rise and fall in usage compared with a slight but continual increase in the use of I would think. Consistent with this trend, the (frequent) use of hypothetical I should in the novel will strike a reader in the $21^{\text {st }}$ century as somewhat archaic, creating a slightly jarring effect on the reader.

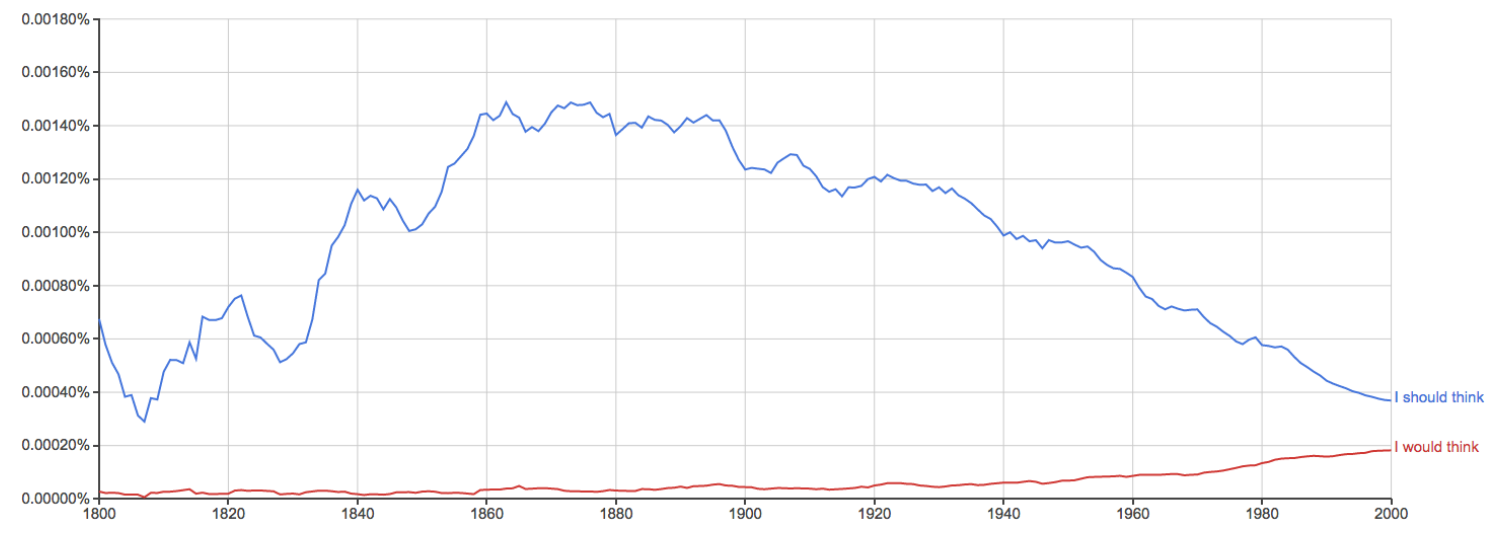

Fig. 1. Ngram Viewer graph of the rise and fall in the use of I should think vs. the steady increase in I would think 1800-2000 in the corpus English Fiction

Figure 2 is a diagrammatic representation of how the imaginary events in these six examples may be (very roughly) represented in an epistemic model of a speaker's reality and its opposite, irreality, adapted from the idealized cognitive model in Langacker (1991, p. 243). In this representation, a conceptualizer's conception of known reality, shown in white, is divided into immediate reality and recent reality. Figure 2 depicts the evolution of known reality and conceptions of irreality through time, from left to right, along the time line $t$. The immediate reality is centered on the current speech event in the most prototypical instantiation of this model. A speech event such as an utterance is not a single point in time, but must be understood as extending through some moments of time, hence the zig-zag line representing a changing, evolving immediate reality. The immediate reality is where this model is 'grounded', indicated by $G$. Irreality in this figure is indicated by the shaded area, and is understood as including conceptualizations of everything other than known reality (see Langacker 1991, pp. 242-243, for more discussion), which can be located in the past, present, future, or some combinations of these. In the case of a narrated fictional novel as we are dealing with, immediate reality may be understood as the current sentence being processed by a reader, with the time line running from the beginning of the novel to the end of the novel. The past, present and future divisions of the cognitive model in the case of a novel refer to the narrative past, present and future. In Figure 2 a rough indication has been given for the location of each of the imagined scenarios associated with each of the first five examples discussed above examples. 


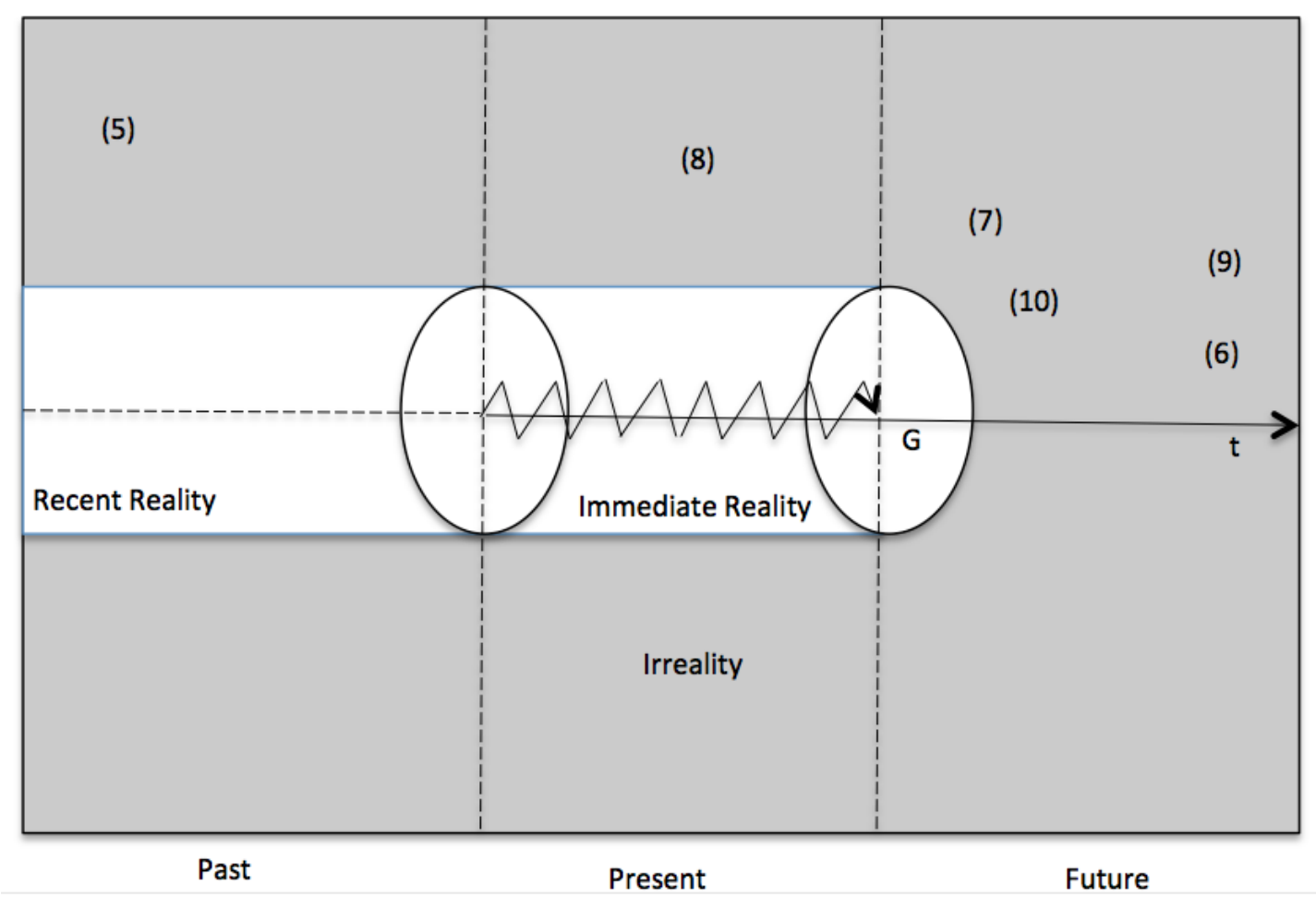

Fig. 2. An epistemic model showing the location of the imaginary scenes of examples (5)-(10)

The epistemic model underlying Figure 2 proves useful, too, when it comes to better understanding different cognitive paths that lead the reader to irreality. The examples in (11) and (12) illustrate two distinct cognitive paths. The passage in (11) includes the opening words of the novel where the narrator introduces the reader to a dream she experienced the previous night. The reporting of the dream is located in the narrative recent reality (last night) and the imaginary space is introduced as a dream on the part of the narrator (I dreamed). From there, the reader is led to the summary content of the dream (I went to Manderly again). The reporting of the dream continues in the rest of the paragraph and, in fact, the whole chapter. I refer to this kind of path into imaginary space as an indirect path; it represents an explicitly sign-posted transition to the imaginary space that is elaborated in the rest of the paragraph, with the content of the dream expressed in the complements clause of dreamt. (12), on the other hand, can be taken as an example of a direct path into the irreality. It begins with a reference to the recent reality in which the narrator has been informed that she will be leaving the hotel where she has fallen in love with Maxim de Winter, expressed in the past perfect and simple past tenses. The third sentence, beginning with Tomorrow evening I should be in the train, ... abruptly, and without any further preparation for a transition into the imaginary space, catapults the reader into irreality, indicated syntactically only by the use of the modal construction I should be in the train. I refer to this transition as a direct path into irreality.

(11) Last night I dreamt I went to Manderley again. It seemed to me I stood by the iron gate leading to the drive, and for a while I could not enter for the way was barred to me. (p.1) 
(12) It had happened at last, the business of going away. It was all over. Tomorrow evening I should be in the train, holding her jewel case and her rug, like a maid,... (p. 51)

Figures 3 and 4 represent the two paths illustrated in (11) and (12), building on the epistemic model introduced above. In these figures, a dashed line indicates the conceptual path taking the reader from the immediate reality of the narrator to irreality. In Figure 3, the representation of the indirect path into irreality exemplified by (11), the reader is first transposed mentally to the recent reality of the preceding night and from there to the irreality of the dream content. The transition into irreality is facilitated by the intermediate step of introducing a dream that occurred in recent reality. Figure 4 shows the different conceptual dynamics at work in example (12). Here the first part of the text associated with the immediate reality refers the reader back to recent reality. The second part of the text involves a direct entry into irreality, unmediated by any introductory reference to dreaming, imagining etc. It is the modal verb should that locates this part of the text in irreality.

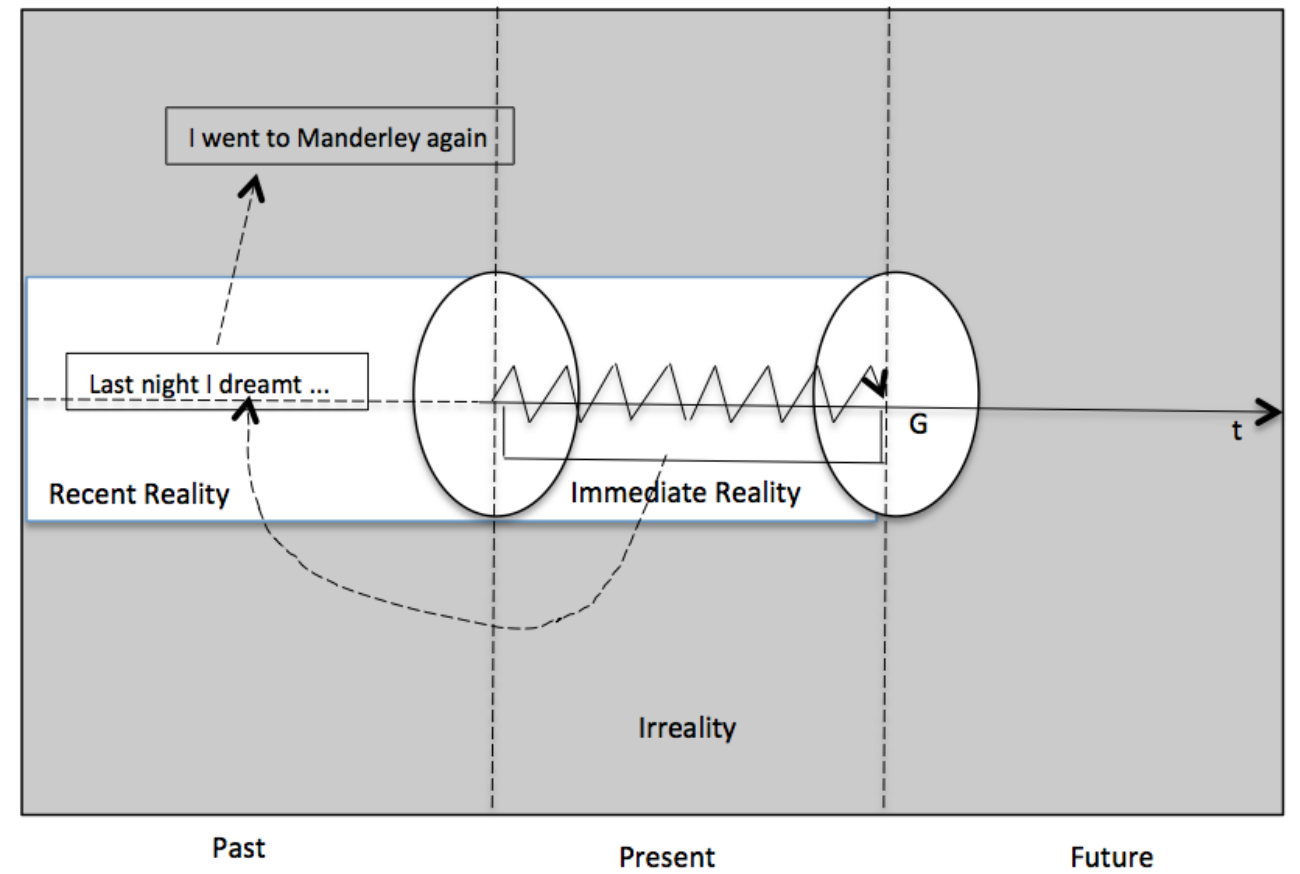

Fig. 3. The epistemic model with reference to example (11), the opening sentence of the novel, showing the indirect path to the imaginary space from immediate reality

The examples in this section have shown some of the richness in the various ways that du Maurier navigates imaginary spaces in Rebecca. As far as the form of the relevant passages is concerned, there is a considerable variety of linguistic devices employed throughout the novel, as seen in examples (5)-(10): explicit referencing of acts of dreaming through lexical items (I thought, I dreamt, I saw myself etc.), modal constructions with shall/should and will/would, and use of the if..., then ... construction. Of all these devices, it is the use of the bare hypothetical 
modals should and would, outside of the if..., then ... construction, that is the most remarkable since it is not a feature of everyday English nor, I would say, is it characteristic of fictional writing in contemporary English. When we consider more the conceptual content of the passages leading to imagined spaces, we appreciate the diversity of cognitive paths involved. I have chosen to highlight here the contrast between relatively direct and indirect cognitive paths leading from immediate narrative reality to narrative irreality. Here, too, it is the use of the hypothetical modals should and would that are responsible for the effect of instantaneous, abrupt transitions that serve to create an impression of a neurotic event on the part of the narrator.

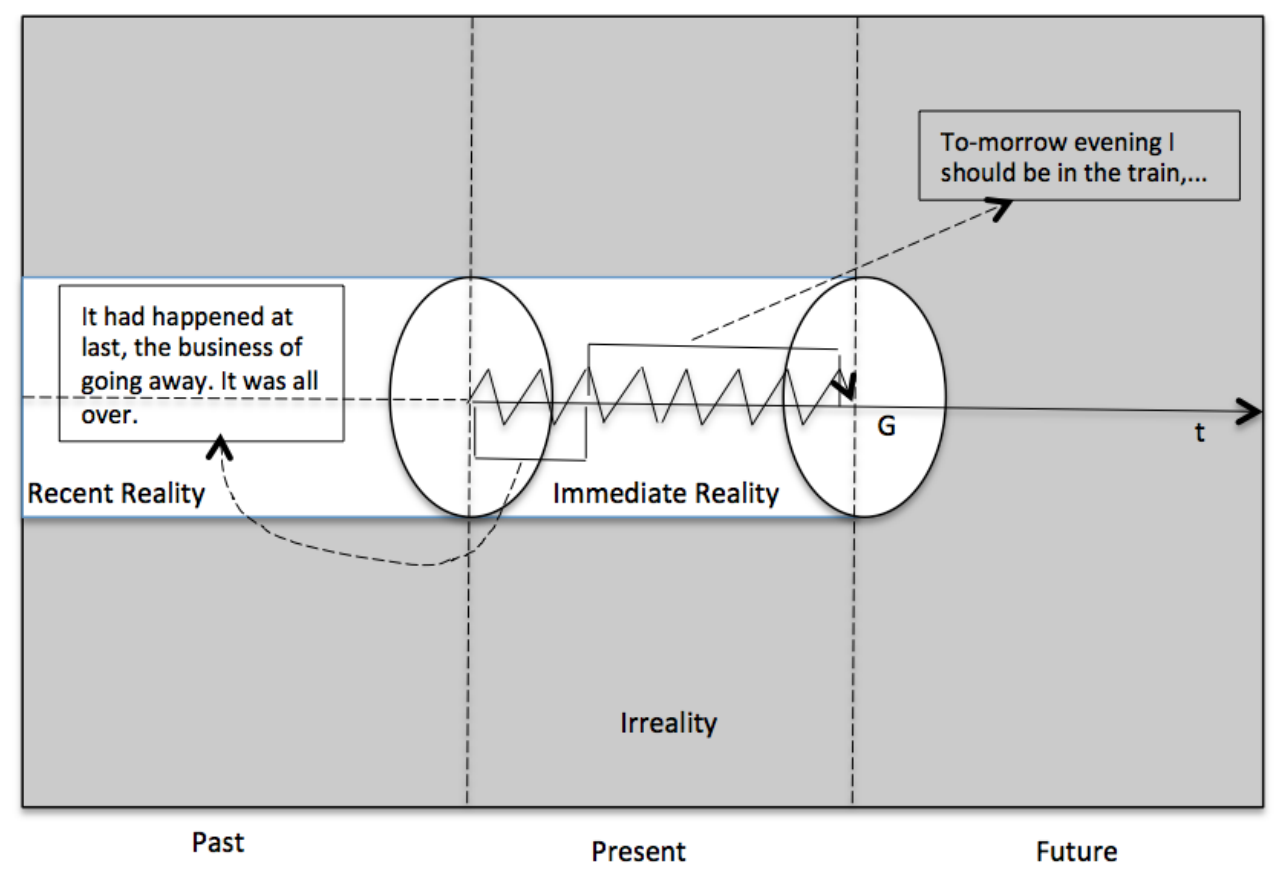

Fig. 4. The elaborated epistemic model with reference to example (12), showing a direct path to the imaginary space from immediate reality

\subsection{Maintaining imaginary narrative spaces}

Apart from the frequency of occurrence of the imaginary spaces in Rebecca, the duration of the story-telling set in these imaginary spaces also deserves comment. The relevant text passages range from momentary, conveyed in a sentence or two, to prolonged. The most sustained story-telling in imaginary space is the very first chapter, the famous opening words of which are quoted in (11) above. The whole chapter is essentially the narration of the dream, expressed for the most part in the past tense. Within that chapter, the house at Manderley, the physical setting for the narrative to come, is introduced and a general foreboding of doom is created.

Without denying the important dramatic effect achieved in Chapter 1 of the novel, I shall turn my attention to another passage that also creates a dramatic effect in the way it maintains quite a prolonged excursion into imaginative space. The passage, consisting of the sequence of paragraphs (pp. 51-53) shown in the Appendix, runs to more than 900 words. The context of the passage is that the 
narrator had just been informed by Mrs. Van Hopper that the two of them would be leaving the hotel imminently and returning to New York. For the narrator, this means suddenly confronting the reality that she will no longer be able to continue with her clandestine relationship with Maxim de Winter, which she had so far managed to keep secret from Mrs. Van Hopper. The sudden news of her impending departure from the hotel (and France) precipitates a psychological crisis for the narrator, a kind of nervous breakdown. For ease of reference, I have labelled the different parts of this passage A-G and I will proceed to discuss the imaginary effect in each of these parts.

The abrupt transition into the imaginary narrative space in passage A has already been mentioned above. Clearly, this is not what one usually associates with 'dreaming'. The description of the narrator as entering the bathroom locking the door, sitting down on the mat, with her head in her hands is more like a small nervous breakdown and points to a neurotic state of mind, imagining future scenarios without Maxim De Winter. The imaginary space is anchored by the uses of should/would throughout these passages (thirteen in total), as shown in bold. Notice that the imaginary space is maintained after the first use through participial phrases: I... holding her jewel case and her rug, ... and she... dwarfed in her furcoat, sitting opposite. After the next modal use, would wash and clean our teeth, the passage continues with a succession of short noun phrases - the splashed basin, the damp towel, etc. - until we reach the last modal, would tell me, after which we once again the participial style: ... sitting alone...reading a book, not minding, not thinking. The choices of participial constructions and successive noun phrases succeed in elaborating on the imaginary space without continually re-anchoring the discourse using the modal construction.

In passage $\mathrm{B}$, we see three modal constructions, again with participial phrases and noun phrases interspersed. The first two instances are separated by a verbless sequence $A$ furtive scrambled farewell, because of her... The text continues after the second modal construction with noun phrases, and a smile, and worlds like...., and then continues with a succession of direct speech quotes as the narrator imagines a hurried farewell with Maxim De Winter. After the third modal construction, the passage continues with a participial phrase (asking a passing waiter for a light) and another direct speech quote. The final sentence of the paragraph uses simply the future tense as a way of marking the certainty of what in the rest of the paragraph has been speculation.

In passage $\mathrm{C}$ we see five modal constructions interspersed with both participial phrases and direct speech quotes. The final clauses of the paragraph, in the simple past tense (because this was the last moment, the final goodbye had been attained), have a similar effect to the use of the simple future tense in passage B, i.e., creating a sense of certainty around the farewell rather than a hypothetical farewell. Passage D continues with direct quotes of imagined speech and then a succession of three modal constructions.

Passage E continues with reflections on an imagined future until the narrator is interrupted by Mrs. Van Hopper at the door of the bathroom, with Mrs. Van Hopper 
accusing the narrator of "dreaming". Immediately after the interruption by Mrs. Van Hopper, the narrator resumes her fantasizing about the future. Five modal constructions appear in the passage, with a mixture of elaborated noun phrases and direct quotes of imagined utterances or written messages from Maxim de Winter. Finally, passage $\mathrm{G}$ signals the end of the flight into irreality as the narrator returns to the reality of preparing for the return trip in a wagon-lit, i.e. a sleeping car on the train.

When read from beginning to end, the sequence of passages A-G presents an exceptionally long and drawn-out excursion into imaginary narrative space on the part of the narrator. The modals should and would do the primary work of anchoring these passages to irreality, but they are used sparingly in any one of these passages. Other linguistic devices are used to carry the burden of continuing the imaginary nature of the content, the same range of devices that can be seen in other imaginary passages in the novel: participial phrases, elaborated noun phrases, imaginary direct speech etc. This mixture of linguistic devices succeeds in creating a certain degree of tension and at the same time avoids a sense of monotony. The tension arises through the repetitions of the same linguistic device in quick sequence, accentuating the same emotion or experience. Only so much repetition of the same device, however, can be effective and too much repetition will turn into an unappealing monotony if allowed to continue unchecked. The should and would modals alternate, indeed have to alternate, with miscellaneous other linguistic constructions to sustain such a prolonged flight of imagination.

Although the focus in this study is the novel Rebecca, it is nevertheless interesting to briefly compare du Maurier's handling of the hypothetic should/would construction with that of another author, Oscar Wilde, specifically Wilde's use of the hypothetical should/would in his novel, The Picture of Dorian Gray, originally published in book form in 1891. The relevant passage, cited from a 1996 edition of his complete works (pp. 72-73), is shown in (12). Here, too, there is a sustained an imaginary space, the imagined future of the painting of himself. At this point in the story, the character Dorian Gray had noticed a change in the portrait which now showed a "marred face" and a "cruel smile", mirroring despicable or sinful behaviour/thoughts on the part of Dorian Gray in the narrative reality, the portrait being the "visible emblem of conscience". Dorian Gray in this passage imagines to himself further ways in which his future behaviour might cause further disfigurement of the figure in the portrait.

(12) Yet it was watching him, with its beautiful marred face and its cruel smile. Its bright hair gleamed in the early sunlight. Its blue eyes met his own. A sense of infinite pity, not for himself, but for the painted image of himself, came over him. It had altered already, and would alter more. Its gold would wither into grey. Its red and white roses would die. For every sin that he committed, a stain would fleck and wreck its fairness. But he would not sin. The picture, changed or unchanged, would be to him the visible emblem of conscience. He would resist temptation. He would not see Lord Henry any more would 
not, at any rate, listen to those subtle poisonous theories that in Basil Hallward's garden had first stirred within him the passion for impossible things. He would go back to Sibyl Vane, make her amends, marry her, try to love her again. Yes, it was his duty to do so. She must have suffered more than he had. Poor child! He had been selfish and cruel to her. The fascination that she had exercised over him would return. They would be happy together. His life with her would be beautiful and pure.

The use of the "bare" hypothetical would construction is striking in (12) and shows that du Maurier by no means represents the extreme when it comes to accumulating such expressions. A total of thirteen instances of the modal would in (12), used consistently to indicate an imagined future, creates an effect of imagination running wild, each imagined and unwanted event leading directly to more imagined and unwanted events. It is a much greater accumulation of hypothetical should/would than du Maurier allows herself anywhere in Rebecca. It feels like an excess in the use of a linguistic device, compared with what we find in Rebecca, especially when we consider passages A-G. Although passages A-G represent an exceptionally long neurotic episode within the novel, the sequence is nevertheless consists of stylistically heterogeneous parts that manage to avert monotony.

The literary effects of repetition of form have been succinctly summarized by Leech in (13)

(13) By underlining rather than elaborating the message, [repetition] presents a simple emotion with force. It may further suggest a suppressed intensity of feeling - an imprisoned feeling, as it were, for which there is no outlet but a repeated hammering at the confining walls of language. (Leech, 1969, p. 79)

As Leech says, repetition can suggest "a suppressed intensity of feeling" and this aptly describes, I believe, the reader experience when processing the A-G passages, apart from the brief relief of passage E. It is an entirely appropriate linguistic device to help convey the kind of mini nervous breakdown of the narrator that is the subject of these passages.

\section{Conclusion}

The imaginary narrative spaces of Rebecca clearly leave a strong impression with readers and invite closer attention in terms of how language is used to create and maintain such spaces. The present study has shown a range of linguistic devices that du Maurier utilized for these purposes. While most of these linguistic devices are available to contemporary writers, the use of the modals should/would outside of any if...then ... construction is less so and its use in the novel strikes a modern reader as somewhat unusual and a little archaic. It has an effect of very abruptly transporting the reader into an imaginary space, compared with expressions such as I thought X, I saw myself doing X, Images came to my mind... etc. This bare 
hypothetical modal use is particularly effective, I suggest, when used to convey a sense of being suddenly overwhelmed by neurotic thoughts. The present study has explored the linguistics of imaginary narrative spaces in just one novel, for the most part, though it is a novel that has a special relevance to the topic in light of the reported experiences of readers. It would be of some interest to document more fully the linguistics associated with the creation of such spaces more generally in literature and the present study may be viewed as a point of reference for future studies along these lines.

A key aspect of the language use associated with the maintenance of imaginary narrative spaces in the novel is repetition of form, at both the lexical level and the constructional level. On the one hand, the repetition of a form or construction is effective in creating a tension and intensity (desirable in certain parts of a narrative). On the other hand, repetition can lead to monotony (generally held to be undesirable, aesthetically speaking). Repetition therefore needs to be constantly managed and constrained to be effective as a stylistic device. The imaginary narrative spaces of Rebecca provide instructive examples of how repetition is managed to create particular effects. While there are some remarkable instances of repetition in the novel, e.g., passages A-G in the Appendix, a brief look at an example from Oscar Wilde's writing has shown that fiction writers can allow themselves even more liberty when it comes to repetition, in some ways more than du Maurier allowed herself. Repetition is a feature of ordinary language use, of course, used for emphasis and exaggeration (they said it over and over again, she went on and on and on, the problem became bigger and bigger etc.) and understanding both ordinary language and literary language use of repetition is necessary if we are to build a complete picture of the conventionalization and creativity found in the use of repetition in language. Corpus-based studies and experimental studies each has an important role to play in such research.

The attention to linguistic devices utilized in creating and maintain imaginary narrative spaces has revealed patterns of form and meaning that should be of general stylistic interest. Du Maurier's literary writing has not been judged previously as linguistically, or stylistically, of particular interest, even by those eager to promote the value of her work. Kelly (1987), for example, refers to her failure as a stylist (her style is "conventional" and her sentences are "unmemorable"), even while admiring her writing in other ways (p. 142). When one considers du Maurier's lexical and syntactic choices within a clause, one might well draw the conclusion that her writing is unremarkable, linguistically speaking, and this may well be what Kelly is referring to. But if one considers, as has been done here, the range of linguistic devices employed for a particular purpose and the role of repetition and variation in the use of these devices at a paragraph level rather than a clause level, then her writing can indeed be seen as idiosyncratic, unconventional, and more interesting than has been assumed. While there has been a change in the appraisal by literary critics of du Maurier and her novel Rebecca, long overdue in the opinion of some, it would appear that there is still some reappraisal necessary when it comes to an appreciation of her literary style. 


\section{References}

Armitt, L. (2000). Contemporary women's fiction and the fantastic. New York: St. Martin's Press.

Beauman, S. (2003). Afterword. In Daphne du Maurier's Rebecca (pp. 429-441). London: Virago Press.

Biber, D., Johansson, S., Leech, G., Conrad, S., \& Finnegan, E. (Eds.) (1999). Longman grammar of spoken and written English. Harlow, UK: Pearson Education Limited.

Birch, D. (2007). Addict of fantasy. The Times Literary Supplement, 5447-5448, 17-18.

Dancygier, B. (2012). The language of stories: A cognitive approach. Cambridge: Cambridge University Press.

Dancygier, B. (2017a). Introduction. In B. Dancygier (Ed.), The Cambridge handbook of cognitive linguistics (pp. 1-10). Cambridge: Cambridge University Press.

Dancygier, B. (2017b). Cognitive Linguistics and the study of textual meaning. In B. Dancygier (Ed.) The Cambridge handbook of cognitive linguistics (pp. 607-622). Cambridge: Cambridge University Press.

Du Maurier, D. (2012). Rebecca. London: Virago Press.

Emmott, C. (1997). Narrative comprehension: A discourse perspective. Oxford: Oxford University Press.

Evans, V., \& Green, M. (2006). Cognitive linguistics: An introduction. Edinburgh: Edinburgh University Press.

Fauconnier, G. (1985). Mental spaces: Aspects of meaning construction in natural language. Cambridge: Cambridge University Press.

Forster, M. (1993). Daphne Du Maurier. London: Chatto \& Windus.

Gavins, J. (2007). Text world theory: An introduction. Edinburgh: Edinburgh University Press.

Hadiyanto, H. (2010). The Freudian psychological phenomena and complexity in Daphne Du Maurier's "Rebecca" (A psychological study of literature). LITE: Jurnal Bahasa, Sastra, Dan Budaya 6(1), 14-25. Available at: https://publikasi.dinus.ac.id/index.php/lite/article/ view/1348/1014.

Harrison, C., Nuttall, L., Stockwell, P., \& Yuan, W. (Eds.) (2014). Cognitive grammar in literature. Amsterdam \& New York: John Benjamins.

Harrison, C., \& Stockwell, P. (2014). Cognitive poetics. In J. Littlemore and J. R. Taylor (Eds.), The Bloomsbury companion to cognitive linguistics (pp. 218-233). London: Bloomsbury.

Horner, A., \& Zlosnik, S. (1998). Writing, identity, and the Gothic imagination. London: Macmillian.

Huddleston, R. (2002). The verb. In R. Huddleston \& G. K. Pullum (Eds.), The Cambridge grammar of the English language (pp. 71-212). Cambridge: Cambridge University Press.

Kelly, R. (1987). Daphne du Maurier. Boston: Twayne Publishers.

Lakoff, G., \& Turner, M. (1989). More than cool reason: A field guide to poetic metaphor. Chicago \& London: The University of Chicago Press.

Langacker, R. W. (1991). Foundations of cognitive grammar. Vol. II: Descriptive application. Stanford, CA: Stanford University Press.

Leech, G. N. (1969). A linguistic guide to English poetry. London: Longman Group Limited.

Margawati, P. (2010). A Freudian psychological issue of women characters in Daphne Du Maurier's novel Rebecca. LANGUAGE CIRCLE: Journal of Language and Literature IV(2), 121-126. Available at: https://journal.unnes.ac.id/nju/index.php/LC/article/viewFile/900/839

Naszkowska, K. (2012). Living mirror: The representation of doubling identities in the British and Polish women's literature (1846-1938). Doctoral dissertation, The University of Ed inburgh.

Palmer, F. R. (1974). The English verb. London: Longman Group Limited.

Stockwell, P. (2002). Cognitive poetics: An introduction. London \& New York: Routledge.

Turner, M. (1996). The literary mind. New York \& Oxford: Oxford University Press. 
Turner, M. (2015). Blending in language and communication. In E. Dąbrowska \& D. Divjak (Eds.), Handbook of cognitive linguistics (pp. 211-232). Berlin \& Boston: de Gruyter Mouton.

Werth, P. (1999). Text worlds: Representing conceptual space in discourse (M. Short, Ed.). Harlow, UK: Longman.

Wilde, O. (1996). The picture of Dorian Gray. In The complete Oscar Wilde: The complete stories, plays and poems of Oscar Wilde (pp. 11-161). New York: Quality Paperback Book Club.

Winifrith, T. J. (1979). Daphne du Maurier. In J. Vinson (Ed.), Novelists and prose writers (Great writers of the English language) (pp. 354-357). New York: St. Martin's Press.

Appendix (du Maurier 2012: 51-53)

Passage A:

I could not face the office right away. I went into the bathroom and locked the door, and sat down on the cork mat, my head in my hands. It had happened at last, the business of going away. It was all over. To-morrow evening I should be in the train, holding her jewel case and her rug, like a maid, and she in that monstrous new hat with the single quill, dwarfed in her fur-coat, sitting opposite me in the wagon-lit. We would wash and clean our teeth in that stuffy little compartment with the rattling doors, the splashed basin, the damp towel, the soap with a single hair on it, the carafe half-filled with water, the inevitable notice on the wall 'Sous le train would tell me that the miles carried me away from him, sitting alone in the restaurant of the hotel, at the table I had known, reading a book, not minding, not thinking.

Passage B:

I should say good-bye to him in the lounge, perhaps, before we left. A furtive, scrambled farewell, because of her, and there would be a pause, and a smile, and words like "Yes, of course, do write," and "I've never thanked you properly for being so kind," and "You must forward those snapshots," "What about your address?" "Well, I'll have to let you know." And he would light a cigarette casually, asking a passing waiter for a light, while I thought, "Four and a half more minutes to go. I shall never see him again."

\section{Passage C:}

Because I was going, because it was over, there would suddenly be nothing more to say, we would be strangers, meeting for the last and only time, while my mind clamoured painfully, crying "I love you so much. I'm terribly unhappy. This has never come to me before, and never will again." My face would be set in a prim, conventional smile, my voice would be saying, "Look at that funny old man over there, I wonder who he is, he must be new here." And we would waste the last moments laughing at a stranger, because we were already strangers to one another. "I hope the snap-shots come out well," repeating oneself in desperation, and he "Yes, that one of the square ought to be good, the light was just right." Having both of us gone into all that at the time, having agreed upon it, and anyway I would not care if the result was fogged and black, because this was the last moment, the final good-bye had been attained.

Passage D:

"Well," my dreadful smile stretching across my face, "thanks most awfully once again, it's been so ripping . . ." using words I had never used before. Ripping: what did it mean? - God knows, I did not care; it was the sort of word that schoolgirls had for hockey, wildly inappropriate to those past weeks of misery and exultation. Then the doors of the lift would open upon Mrs. 
Van Hopper and I would cross the lounge to meet her, and he would stroll back again to his corner and pick up a paper.

\section{Passage E:}

Sitting there, ridiculously, on the cork mat of the bathroom floor I lived it all, and our journey too, and our arrival in New York. The shrill voice of Helen, a narrower edition of her mother, and Nancy, her horrid little child. The college boys that Mrs. Van Hopper would have me know, and the young bank clerks, suitable to my station. "Let's make Wednesday night a date." "D'you like hot music?" Snub-nosed boys, with shiny faces. Having to be polite. And wanting to be alone with my own thoughts as I was now, locked behind the bathroom door. . . .

She came and rattled on the door. "What are you doing?"

"All right — I'm sorry, I'm coming now," and I made a pretence of turning on the tap, of bustling about and folding a towel on a rail.

She glanced at me curiously as I opened the door. "What a time you've been. You can't afford to dream this morning, you know, there's too much to be done."

Immediately after the interruption by Mrs. Van Hopper, the narrator resumes her fantasizing about the future. Five modal constructions appear in the passage, with a mixture of elaborated noun phrases and direct quotes of imagined utterances or written messages from Maxim de Winter.

\section{Passage F:}

He would go back to Manderley, of course, in a few weeks, I felt certain of that. There would be a great pile of letters waiting for him in the hall, and mine amongst them, scribbled on the boat. A forced letter, trying to amuse, describing my fellow passengers. It would lie about inside his blotter, and he would answe $r$ it weeks later, one Sunday morning in a hurry, before lunch, having come across it when he paid some bills. And then no more. Nothing until the final degradation of the Christmas card. Manderley itself perhaps, against a frosted background. The message printed, saying "A happy Christmas and a prosperous New Year from Maximilian de Winter." Gold lettering. But to be kind he would have run his pen through the printed name and written in ink underneath "from Maxim," as a sort of sop, and if there was space, a message, "I hope you are enjoying New York." A lick of the envelope, a stamp, and tossed in a pile of a hundred others.

Passage G:

"It's too bad you are leaving to-morrow," said the reception clerk, telephone in hand, "the Ballet starts next week you know. Does Mrs. Van Hopper know?" I dragged myself back from Christmas at Manderley to the realities of the wagon-lit. 